DOI: https://doi.org/10.31933/dijemss.v2i5

Received: $30^{\text {th }}$ May 2021, Revised: $20^{\text {th }}$ June 2021, Publish: $8^{\text {th }}$ July 2021

\begin{tabular}{|c|c|c|}
\hline PINASTISTR & $\begin{array}{l}\text { DIJEMSS } \\
\text { DINASTI INTERNATIONAL JOURNAL } \\
\text { OF EDUCATION MANAGEMENT AND } \\
\text { SOCIAL SCIENCE }\end{array}$ & $\begin{array}{r}\text { https://dinastipub.org/DIJEMSS } \\
\text { editor@dinastipub.org } \\
08117401455 \text { ( }\end{array}$ \\
\hline
\end{tabular}

\title{
DEVELOPMENT OF 3D AUGMANTED REALITY TEACHING MATERIALS BASED ON VIRTUAL TECHNOLOGY AS LEARNING MEDIA
}

\author{
Fattachul Huda Aminuddin ${ }^{1}$, Teuku Djauhari² \\ ${ }^{1)}$ Faculty of Computer Science, Universitas Nurdin Hamzah, fatachulhuda16@gmail.com \\ ${ }^{2}$ Faculty of Computer Science Universitas Nurdin Hamzah, technikom@gmail.com
}

Corresponding Author: Author ${ }^{1}$

\begin{abstract}
Augmented Reality is a concept that combines virtual reality with world and a way to explore 3D objects. This game-based learning application has advantages in terms of more interactive and effective use, and is complemented by simple object modelling that can be widely applied in various media and is very supportive of interface technology through smartphone applications. The purpose of this research is to produce a learning media product by utilizing the development of Augmanted Reality- based 3D Virtual Technology using the marker and Unity 3D platforms in high school ICT Subjects in learning in the era of the industrial revolution 4.0 which is valid, practical and effective to foster critical thinking skills, improving and developing life skills that are realized through the achievement of student competencies. The type of research used is development research with a 4D (Four-D) model approach including the stages of define, design, develop and disseminate. Based on the results of the validation test research, the results obtained from the Content aspect of the media were 0.835 with the Valid category, from the media experts assessed from the media format aspect of 0.84 in the Valid category, and the media presentation aspect obtained Aiken's V value of 0.845 with the Valid category. The practicality of Augmanted Reality-based 3D Virtual Media was obtained from the teacher's response and student responses, from the teacher's response it was obtained an average of $88.57 \%$ with the very practical category and the student response was $81.63 \%$ with a very practical level of practicality. The effectiveness of 3D virtual media based on Augmanted Reality is obtained from the students' learning scores after using the media with the number of students who passed is 17 students $(85 \%)$ out of 20 students and stated that the media is effective to improve student learning outcomes through the Gain score test with a value of 0.53 with category moderate. It is hoped that this application and can be developed again by researchers so that this application can help and support teachers in supporting the success of the student learning process.
\end{abstract}

Keyword: Augmented Reality, Vuforia, Unity, Virtual 3D , 4D (Four-D), ICT Subject

\section{INTRODUCTION \\ BACKGROUND OF THE PROBLEM.}

ICT subjects that have characteristics as skills in using computers include hardware and software (Jumriana, 2015). In ICT learning, teachers are required to be creative in creating effective learning (Riyanda, 2019). Yehezkel (2010) stated that there are four limitations to the assessment of learning outcomes in ICT family subjects, namely pengetahuan teori (theoretical knowledge), pengetahuan teknis (technical knowledge), added value obtained by students during learning (value added), students good habits (good habit). Then, (Kennewell, 2003), ), states that the assessment of learning outcomes in ICT subjects must be able to distinguish what includes aspects of skills, 
attitudes, concepts, and knowledge. Integrating Information and Communication Technology into the learning process can improve Information Communication and Technology literacy, build characteristics of a knowledge-based society, in students, in addition to increasing the effectiveness and efficiency of the learning process itself.

The results showed that in the implementation of learning ICT subjects in schools, teachers still use conventional learning systems with teacher-centered, the type of learning media applied by teachers of ICT subjects, namely print-based media (textbooks), and have not used multimedia learning as a learning medium (Kuswanto, 2017). In line with that, according to Diansyah (2015) in his research, it was stated that the facilities and the non-withdrawal of teaching materials that were revised by the teacher on subjects resulted in the low absorption of students. The limitations of learning media make students have difficulty understanding the teaching material and the effectiveness of practicum is less (Suhiyar, 2017). The difficulty that is generally found in schools is the lack of teacher skills in using software or programming in making multimedia interactive learning (Tomei, 2007).

The Industrial Revolution 4.0 in the world of education is marked by the initiation of interconnection or connecting users to the internet (Zanni-merk, 2018) or in short, learning media assisted by digitalization technology (applications or software). According to Wahono (2007) in his research states that there are two approaches that teachers can take when planning ICT-integrated learning, namely: (1) a theme centered approach; and (2) a software approach (software-centered approach). Therefore, teachers need to apply a software-centered approach in the ICT learning process. The use of multimedia and computer or smartphone-based learning systems need to be applied to present effective and interactive learning materials (Benford et al., 2000; Kortbek and Grønbæk, 2008; Lee et al. 2011; Madden et al., 2008). Riyanda (2019) in his research concluded that the use of the Adobe Flash CS6-based Mobile Learning module is effective for improving learning outcomes.

By using smartphone aids, it is hoped that the learning process that initially only uses books and teaching aids that are monotonous in which the student's brain is forced to remember and store various information can be circumvented by using new technology that can attract students' interest in learning, namely by applying Augmented reality technology ( Wiharto, 2017) Android-based learning can help students understand the material in question in a shorter time and is fun (Suana, 2019).

Augmented reality is a direct or indirect interaction of a real world physical environment that has been added by adding to the virtual computer generated information. Augmented reality is two types of interactive technology and is registered in 3D and combines real and virtual objects (Furh, 2011). Augmented reality is a natural way to explore 3D objects and data Cawood (2007). The advantages of Augmented reality are as follows: 1) More interactive, 2) Effective in use, 3) Can be widely implemented in various media, 4) Simple object modeling, because it only displays a few objects, 5) Making that does not take too much a lot of costs, 6) Easy to operate (Mustaqim, 2017).

Lee (2011) defines that Augmented reality is a way to explore three-dimensional objects and data, Augmented reality is a concept that combines virtual reality with world reality. So that twodimensional or three-dimensional virtual objects appear to be real and one with the real world. This is in line with the concepts contained in ICT subjects which require a lot of complex understanding 
material, not memorization because in ICT material there are images, functions, and parts of computers, Ardianti (2012). Mustika (2015) states that computer subjects that study the introduction of computer hardware, such as: Case Central Processing Unit, Hard disk, Motherboard, Processor, Power Supply, RAM, Vga Card, Sound Card, DVD Room, Floppy. the basis or background for researchers to develop virtual-3D Augmented reality technology that can be accessed via smartphones in ICT learning. With the help of the 3D Augmented Reality visualization application, the components contained on the computer can be observed directly without props. This is what makes Augmented reality 3D visualization a solution in ICT learning.

This research was conducted because of the encouragement of the writer who saw the current learning conditions which tended to still use image media that was packaged using powerpoints and made use of learning videos that were only seen, and seemed monotonous. Lack of teacher creativity is one of the factors inhibiting the learning process in utilizing technology that has developed today. So that the need for media that is able to give the impression of a more real visual stimulation.

\section{FORMULATION OF THE PROBLEM}

Berdasarkan latar belakang akan di rumuskan masalah yang akan di bahas pada artikel literature review agar lebih focus pada kajian pustaka dan hasil serta pembahasan nanti, yaitu:

1. How to develop teaching materials for the development of 3D Augmanted Reality Teaching Materials based on Virtual Technology as a Learning Media.

2. How to develop teaching materials for the Development of 3D Augmanted Reality Teaching Materials based on Virtual Technology as a valid, practical, and effective Learning Media

\section{THEORITICAL REVIEW}

Learning media, especially ICT, develop along with the development of ICT, both learning media in the form of images and videos. Many development researches in Indonesia are competing to use ICT-based learning media. The development of the 21 st century, Indonesia is still developing learning media from 2D simulations (Setiawan, 2016; Fauzi, 2017). It lags behind developing countries where ICT-based learning media have achieved 3D simulations. On the positive side, Indonesia is currently developing a lot of 3D simulations or visualizations (Dzikiri, 2016; Fathoni, et al., 2016; Ramadhan, et al., 2017).

Augmented reality is the development of virtual reality. But both have very clear differences, namely virtual reality tries to change all real environments into virtual or virtual forms, by adding some real objects for specific purposes. Meanwhile, Augmented reality tries to add virtual elements or objects to the real world or be understood by incorporating virtual into the real environment, so that users are sure that the environment is really real which is integrated through certain input devices, and good integration requires good exploration. . effective (Ardhianto, et al, 2012) which runs interactively in real time, and there is integration between objects in three or two dimensions, namely virtual objects that are integrated in the real world (Ronald, 1997). And can be applied with an online learning system model.

The online learning system can optimize the interaction between lecturers and students through discussion forums in the media (Riyanda, et al, 2020). (Pratama, 2015) in his research said 
that learning media that still use text books, pictures and presentation slides can be converted into virtual learning media using augemented reality, so that they become interactive learning media.

Not only in the world of education, the use of augemented reality technology can also be used in various fields including in the world of health, Nasrullah (2019) uses augemented reality technology to create educational media to provide understanding to the public regarding nutritional value. information to address nutritional problems. Augmented reality applications can be applied to an android-based catalog application. Research conducted by (Rifa'i, 2014) is to produce an application that can display 3D home models in an environment that can help buyers get to know the house to be purchased, and will make it easier for home sellers as a promotional medium to consumers.

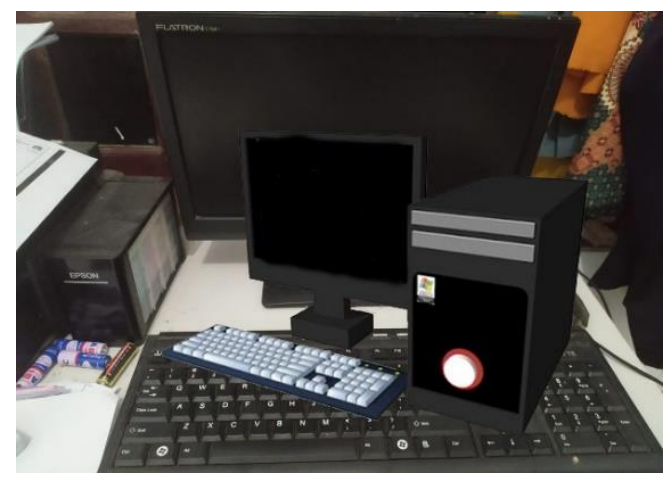

Figure 1: One of the 3D Augmented Reality Visualizations

Augmented reality technology is one of the breakthroughs used recently in the field of interaction. The use of this technology will be very helpful in conveying information to users (Vert, 2015). Augmented Reality is an interaction technology that combines the real world and the virtual world. In augmented reality technology, there are three basic characteristics, including the combination of the real and virtual worlds, real-time interactions, and the last characteristic is the shape of an object in the form of 3 dimensions or 3D. The form of contextual data in augmented reality can be in the form of location data, audio, video ataupun dalam bentuk model and 3D animation (R. Pierdicca, et. al. 2015). In general, the components needed in making augmented reality are:

\section{Computer \\ 2.Marker \\ 3.Camera}

Basically, the working principle of Augmented Reality is tracking and reconstruction. At first the marker was detected using the camera. Detection methods can involve various kinds of algorithms such as edge detection, or other image processing algorithms. The data obtained from the tracking process is used in the reconstruction of the coordinate system in the real world. Besides adding objects to the real environment, Augmented Reality can also eliminate real objects in virtual form. By covering the real object with a graphic design according to its environment, the real object will be hidden from the user. 


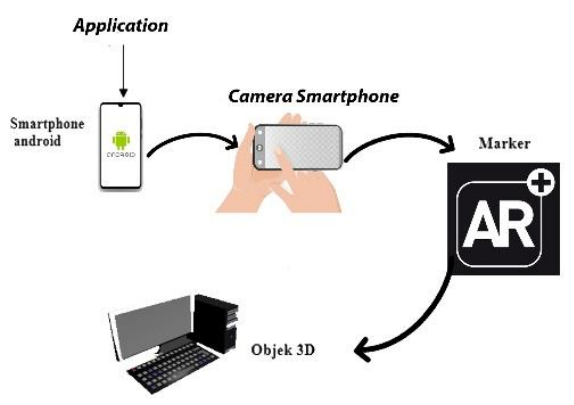

Figure 2 : Augment Reality Work Diagram

This 3D augmented reality has been researched by previous researchers, including (Maulana, 2017) regarding the application of Augmented reality for product marketing using Unity 3D and Vuforia software. This is similar to research conducted on previous researchers (Hakim, 2018) regarding the development of Augmented Reality-based pie learning media.

\section{WRITING METHOD}

The method used in this research is research and development. This study aims to obtain a valid, practical and effective 3D virtual 3D software product based on the component material of computer equipment as a supplement or support for high school ICT learning. In the research and development method, there are several types of models, one of which is the 4-D (Four D) development model. This development model consists of 4 stages including Define, Design, Develop and Disseminate. This model has advantages when used in the development of learning device products (not learning systems), because the stages of implementation are divided in detail and systematically.

\section{Development Procedure}

\section{a. Definition Stage (Define)}

This definition stage is carried out to get an overview of conditions in the field related to the learning process of ICT subjects. At this stage there are three things that are done, namely observation, curriculum analysis and student analysis.

\section{b. Planning Stage (Design)}

The choice of virtual-3D Augmented reality technology was made because it was relevant to the characteristics of the learning material. In addition, Augmented reality virtual-3D technology media was also selected in accordance with the analysis of student needs and characteristics analysis. The research instrument consisted of 1) a validation sheet for the development of virtual-3D Augmented Reality technology, 2) a practicalization sheet, 3) an analysis sheet for student learning outcomes.

\section{Development Stage (Develop)}

1. Designing the Prototype

Creating an initial design (propotype) of virtual-3D Augmented reality technology media whose content is adjusted to the applicable syllabus and lesson plans.

2. Validation Stage 
The validation process is accompanied by direct discussions or interviews with experts regarding improvements that must be made by means of a virtual-3D Augmented reality technology media design that is first consulted with experts or experts and supervisors, then the design is assessed by competent people (validators) who have understood the principles of media development.

3. Practicality Stage

Augmented reality virtual-3D technology media is said to have high practicality if it is practical, easy to administer. In the sense that it is easy to use, easy to check and complete with clear instructions. At this stage the data collection was carried out with a practicality questionnaire by teachers and students. The teacher's questionnaire on the practicality of the media contained the ease of use of the media, the time it used, it was easy to interpret, and the media equivalence.

4. Effectiveness stage

This stage is carried out to assess whether the media developed can be used as expected to improve the quality and learning outcomes of students. The instrument used to collect data on the effectiveness of the media was a test.

\begin{tabular}{|r|c|c|}
\multicolumn{1}{|c|}{ Table 1 Product Trial Design } \\
\begin{tabular}{|r|c|c|}
\hline Pretest & Treatment & Posttest \\
\hline$O_{1}$ & $\mathrm{X}$ & $O_{2}$ \\
\hline
\end{tabular} \\
\hline
\end{tabular}

\section{Deployment Stage (Disseminate)}

the dissemination stage will be carried out by means of media socialization through distribution in limited quantities to teachers and students. This distribution is intended to obtain responses and feedback to the developed media.

\section{Data Analysis Technique}

\section{Analysis of Media Validity}

The content and media validation analysis is based on the results of the validator's assessment. The data obtained through a questionnaire were analyzed using descriptive statistics. The steps for conducting the analysis, namely:

a. Determine the average score obtained by adding up the scores obtained from many indicators.

b. Aiken's V statistics are defined as $\mathrm{V}=\sum \mathrm{s} /[\mathrm{n}(\mathrm{c}-1]$

Information :

$\mathrm{s}=\mathrm{r}-\mathrm{lo}$

lo $=$ low number of validity assessments (in this case $=1$ )

$\mathrm{c}=$ the highest number of validity assessments (in this case $=4$ )

$\mathrm{r}=$ The number given by an assessor

c. The results of Aiken's calculations range from 0 to 1 and the number 0.6 can be interpreted as having a high enough coefficient, so the value of V 0.6 and above is stated in the valid category

\section{Questionnaire analysis of media practicality.}

The results of research through questionnaires on the media from teachers and students. The assessment will get responses or opinions from lecturers and students to determine the practicality of the media. 
a. Determine the average score obtained by adding the scores obtained from many indicators.

b. Giving practical value with the formula:

$\mathrm{NA}=\mathrm{S} / \mathrm{M} \times 100 \%$

Information

$\mathrm{NA}=$ Final score

$\mathrm{S} \quad=$ Score obtained

$\mathrm{SM}=$ Maximum Score

\section{Media Effectiveness Analysis.}

Effectiveness analysis is used to measure the level of student learning completeness obtained from student learning outcomes using test instruments.

a. Effectiveness Test

1) Gain Score Test

After doing research and doing calculations to see the improvement in student learning outcomes using the gain score formula. The virtual-3D Augmented Reality technology media developed can be said to be effective if the gain score is $>0.30$ or at least in the medium category.

2) $\mathrm{T}$ test

$\mathrm{T}$ test to compare the condition of the object of research before and after treatment can be tested with the following t-test formula

$t=\frac{\bar{X}_{1}-\bar{X}_{2}}{\sqrt{\frac{s_{1}{ }^{2}}{n_{1}}+\frac{s_{2}{ }^{2}}{n_{2}}-2 r\left(\frac{s_{1}}{\sqrt{n_{1}}}\right)\left(\frac{s_{2}}{\sqrt{n_{2}}}\right)}}$

Information

$\mathrm{t}=$ The value of $\mathrm{t}$ count

$\mathrm{X}_{-}^{-} 1=$ rata-rata nilai posttest

$\mathrm{X}_{-}^{-} 2=$ the average posttest score

$\mathrm{S} \_1$ = Posttest standard deviation

$\mathrm{S} \_2$ = pretest standard deviation

$\mathrm{n} \_1=$ many pretest subjects

$\mathrm{n} \_2$ = many subjects posttest

$\mathrm{r} \quad=$ correlation between two samples

\section{DISCUSSION}

Bagian ini menyajikan semua data yang dikumpulkan dari setiap tahap pengembangan media

1. Define Stage

a. Curriculum Analysis

This curriculum analysis refers to the syllabus and lesson plans for ICT subjects. The material / subject that was developed in the virtual-3D technology media. Augmented Reality is a topic being developed is computer hardware

b. Analysis of Student Characteristics

Based on the analysis of these students, it is taken into consideration in the development of virtual-3D Augmented Reality technology media on basic competencies, namely the media developed is in accordance with the conditions and characteristics of students, with this media it is hoped that students can more easily understand ICT subjects. 
2. Design Stage

The results of the analysis from the Defining stage are used for the next stage, namely the design stage. The details of the design stage are as follows:

a. Media Selection

In making this application using Unity 3D and Marker software

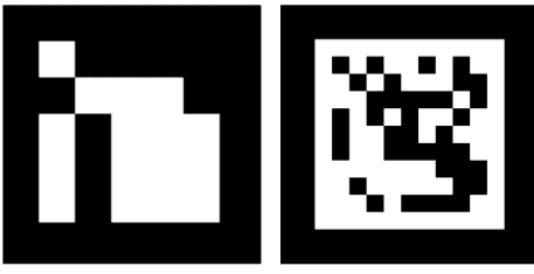

Figure 3 . AR Marker

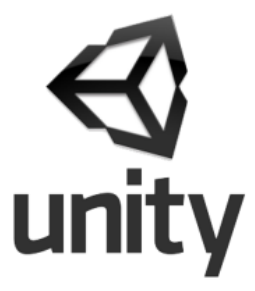

Figure 4. Unity 3D

b. Designing Prototype

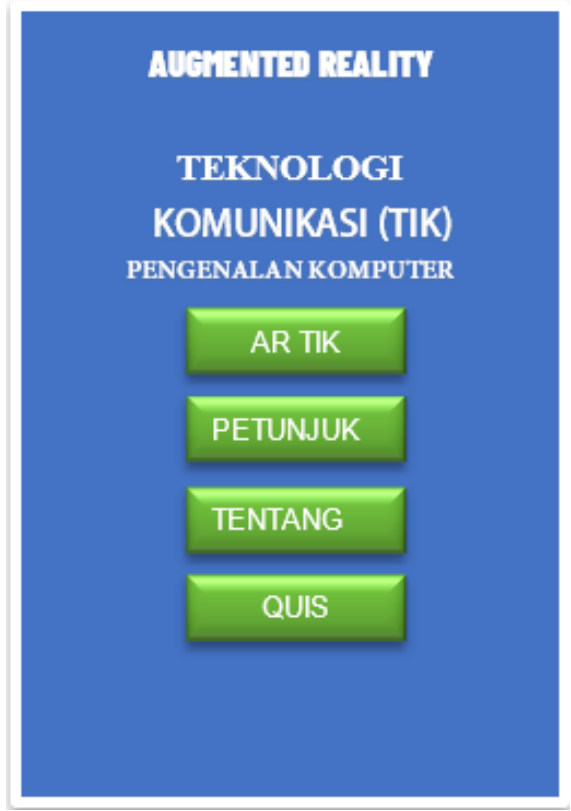

Figure 5. Main Design

c. Media Making

In making Augment Reality 3D media objects using the 3D Unity application 


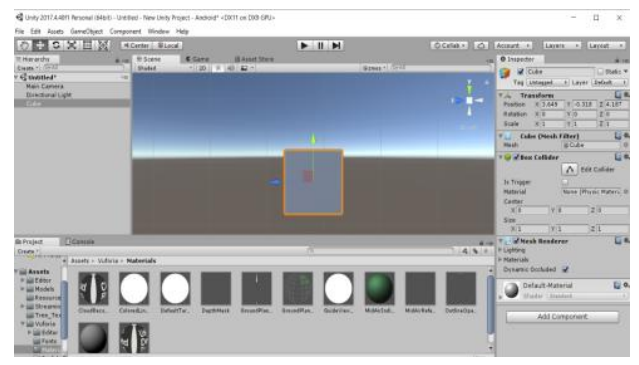

Figure 6. Unity 3D

In order for the media to run optimally, it is necessary to pay attention to the stages expressed by Eka Legya (2015,39-41), namely (1) Stage of Collection of User Requirements Specifications, (2) Stage of Computer Architecture Design (3) Stage of Designing System Components, (4) Interface design stage (5) stage of program development, (6) testing phase

3. Developtment Stage

When the design stage is complete, the next stage is the development stage. This development stage aims to produce valid, practical and effective virtual-3D media based on augmented reality technology. This development stage consists of an assessment of media and material validation by the validator and an assessment of practicality by teachers and students. And at the end, a test is conducted to determine the level of effectiveness of the interactive learning media being developed.

Table 2. the validator's assessment of the content (content)

\begin{tabular}{|l|l|c|c|}
\hline No & Indicator & Aiken's V & Ket \\
\hline 1 & Indicator 1 & 0,83 & Valid \\
\hline 2 & Indicator 2 & 0,84 & Valid \\
\hline Amont & 0,85 & Valid \\
\hline
\end{tabular}

Table 3. the validator's assessment of the media format

\begin{tabular}{|l|l|c|c|}
\hline No & Indicator & Aiken's V & Ket \\
\hline 1 & Indicator 1 & 0,85 & Valid \\
\hline 2 & Indicator 2 & 0,83 & Valid \\
\hline Amont & & 0,85 & Valid \\
\hline
\end{tabular}

Table 4. validator's assessment of presentation

\begin{tabular}{|l|l|c|c|}
\hline No & Indicator & Aiken's V & Ket \\
\hline 1 & Indicator 1 & 0,83 & Valid \\
\hline 2 & Indicator 2 & 0,86 & Valid \\
\hline Amont & 0,845 & Valid \\
\hline
\end{tabular}

At this stage, a field test was carried out to determine the practicality of the virtual-3D Augmented Reality technology media that had been developed. Practicality test data were obtained from filling out a media practicality questionnaire.

a. Teacher's Response to Media Practicality 
Table 5 practicality assessment table by the teacher

\begin{tabular}{|l|l|c|c|}
\hline No & Respondents & Presentase & Ket \\
\hline 1 & Validator 1 & $88,29 \%$ & Very Practical \\
\hline 2 & Validator 2 & $90,86 \%$ & Very Practical \\
\hline \multicolumn{2}{|l|}{ Amount } & $88,57 \%$ & Very Practical \\
\hline
\end{tabular}

b. Student Response to Media Practicality

The results of practicality data analysis through student responses showed that the practicality value of Augmented reality-based virtual-3D technology in the ICT eye was $81.63 \%$ at a very practical level.Efektivitas penggunaan media teknologi virtual-3D berbasis Augmented reality pada mata pelajaran TIK ditinjau dengan cara menghitung data pretest dan posttest menggunakan analisis Uji gain score.

Table 6. pretest data analysis results

\begin{tabular}{|c|c|}
\hline Valid & 20 \\
\hline Missing & 0 \\
\hline Mean & 61,5380 \\
\hline Median & 61,5400 \\
\hline Mode & 57,69 \\
\hline Std. Deviation & 13,72688 \\
\hline Variance & 188,427 \\
\hline Minimum & 38,46 \\
\hline Maximum & 84,62 \\
\hline Sum & 1230,76 \\
\hline
\end{tabular}

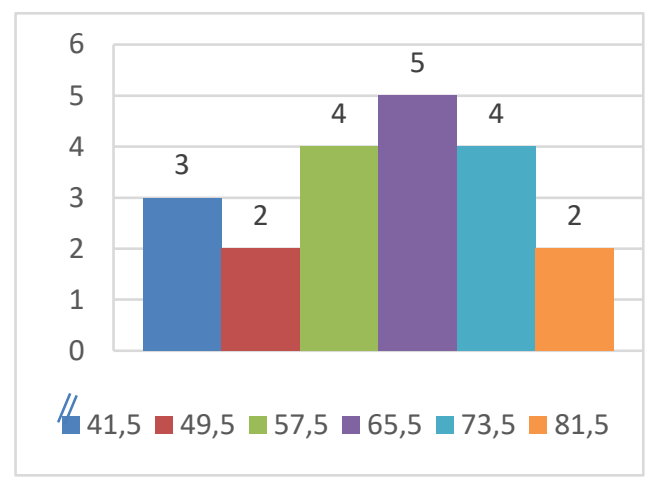

Figure 7. Histograms of Pretest Values

Tabel 7 the results of the statistical calculation of the posttest value

\begin{tabular}{|l|r|}
\hline \multicolumn{1}{|c|}{$\mathrm{N}_{\text {Missing }}$} & 20 \\
Mean & 0 \\
Median & 81,9240 \\
Mode & 80,7700 \\
Std. Deviation & 80,77 \\
Variance & 8,09741 \\
Minimum & 65,568 \\
Maximum & 65,38 \\
Sum & 96,15 \\
& 1638,48 \\
& \\
\hline
\end{tabular}

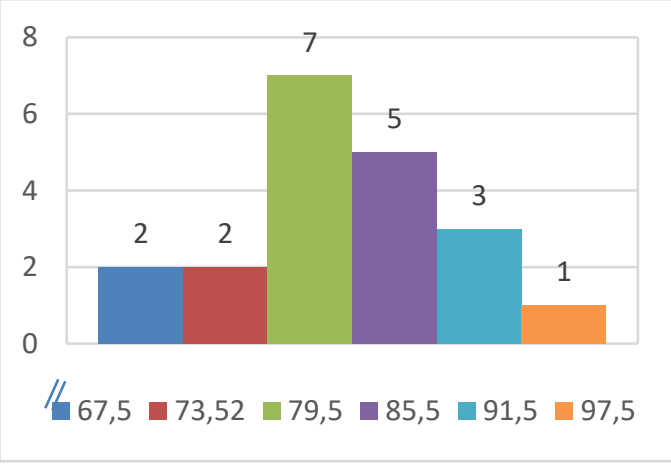

Figure 8 Postest Value Histogram

4. Gain Score Test Results

The gain score test is used to see the increase in student learning outcomes from the pretest and posttest scores. 
Tabel 8. Gain Score Test Results

\begin{tabular}{|l|c|l|c|c|c|c|}
\hline \multirow{2}{*}{ Respondents } & \multicolumn{2}{|c|}{ Prestest } & \multicolumn{2}{c|}{ Posttest } & \multirow{2}{*}{ Gain Score } & \multirow{2}{*}{ Category } \\
\cline { 2 - 7 } & TRUE & Score & TRUE & Score & & \\
\hline Amount & & 1230,77 & Amount & 1638,46 & & \\
\hline Average & & 61,54 & Average & 81,92 & 0,53 & Moderate \\
\hline
\end{tabular}

5. Result of $t$ test

The calculation of t count was carried out using SPSS version 16. The results of the analysis for $t$ count can be seen in the table below

Tabel 9. Hasil Uji t

\begin{tabular}{|c|c|c|c|c|c|c|c|c|c|}
\hline & \multicolumn{2}{|c|}{$\begin{array}{l}\text { Levene's Test } \\
\text { for Equality of }\end{array}$} & \multicolumn{7}{|c|}{ t-test for Equality of Means } \\
\hline & \multirow[t]{2}{*}{$\mathrm{F}$} & \multirow{2}{*}{ Sig. } & \multirow[t]{2}{*}{$\mathrm{t}$} & \multirow{2}{*}{ df } & \multirow{2}{*}{$\begin{array}{l}\text { Sig. (2- } \\
\text { tailed) }\end{array}$} & \multirow{2}{*}{$\begin{array}{c}\text { Mean } \\
\text { Differe } \\
\text { nce }\end{array}$} & \multirow{2}{*}{$\begin{array}{l}\text { Std. } \\
\text { Error } \\
\text { Differe }\end{array}$} & \multicolumn{2}{|c|}{$\begin{array}{c}95 \% \\
\text { Confidence } \\
\end{array}$} \\
\hline & & & & & & & & Lower & Upper \\
\hline \multirow{2}{*}{ nilai } & 10.674 & .002 & 9.300 & 58 & .000 & 20.133 & 2.165 & 15.800 & 24.467 \\
\hline & & & 9.300 & 47.488 & .000 & 20.133 & 2.165 & 15.779 & 24.487 \\
\hline
\end{tabular}

Based on the results of data analysis using SPSS 16, it can be seen that the $t$ count value is 9.300> $\mathrm{t}$ table 1.697 and the significance value is 0.00 which is smaller than 0.05 , it can be concluded that there is a significant difference between the pretest and posttest. Posttest learning outcomes are better than pretest learning outcomes, this can be seen through the average posttest results that are greater than pretest. Thus, it can be concluded that the virtual-3D technology based on augmented reality is effectively used in Class X Senior High School ICT subjects.

\section{CONCLUSION \& SUGGESTION CONCLUSION}

The result of this research is $3 \mathrm{D}$ media technology based on augmented reality in ICT subjects. This media development process refers to the 4-D development model, namely Define, Design, Develop, and Dessiminate. At the defining stage, an analysis of learning needs and student analysis was carried out. The subject of the trial for the development of 3D media technology based on augmented reality are class $\mathrm{X}$ students. After the development stage is complete and the 3D media technology based on augmented reality developed has been declared valid, the media is ready to be distributed. This learning media is distributed to class X SMA 2 Bandar Lampung.

In this development research produced a virtual-3D technology based on augmented reality media that is valid, practical and effective, in the ICT Assembly subject and this media has experienced validity, practicality and effectiveness trials carried out on validators, teachers and students. The virtual-3D technology based on augmented reality that was developed is based on competency standards and basic competences of ICT subjects 


\section{SUGGESTION}

Based on the conclusion above, the suggestion in this article is that more specific development is needed both in terms of software development and more complex material content for students.

\section{BIBLIOGRAPHY}

Ardhianto, E., Hadikurniawati , W ., Winarno ,E., (2012). Augmented Reality of 3 Dimensional Objects with Artoolkit and Blender Devices, DYNAMIC Journal of Information Technology, No.2, Vol. 17, pp. 110-117

Ardianti, N. M. Y. (2012). Development of Interactive Learning Media Based on Team Assisted Individualization for Information and Communication Technology (ICT) Subjects with the Subject of Graphic Design in Class XII Students. National Journal of Informatics Engineering Education: JANAPATI, 1 (3), 219-243

Benford, S., Bederson, B., Akesson, K. P., Bayon, V., Druin, A., Hansson, P., Hourcade, J., Ingram, R., Neale, H., Malley, C., Simsarian, K., Stanton, D., Sundblad, Y., \& Taxen, G. (2000). Designing storytelling technologies to encourage collaboration between young children. In: Proceedings of CHI 2000, The Hague, The Netherlands, 1-6.

Cawood, S., Fiala, M., (2007), Augmented Reality-A Practical Guide, The Pragmatic Bookshell, Raleigh, North Carolina, Dallas, Texas.

Diansyah, A. N. (2015). Application of Interactive Multimedia Tutorial Model for Improving Student Understanding of Concepts in Information and Communication Technology Subjects. QUOTED JOURNAL, 1 (1), 11-18.

Dzikri, Afdhol., Santoso, Wahyu Agung. (2016). 3D Visualization of Solar System with Occlusion Based Method as Learning Media. Proceedings of SENTIA State Polytechnic of Malang. 8 267-272.

Fathoni, Kholid., Hasim, Jauari Akhmad Nur., Fadholani, Choirul., Hakkun, Rizky Yuniar., Asmara, Rengga. (2016). 3D Visualization of Learning the Cause of Global Warming Using Virtual Reality. Journal Links. 25 (2) 16-20..

Fauzi, A., Faradilla, L., \& Summa Dewi, T. (2017, November). Using computer simulation to improve high order thinking skills of physics teacher candidate students in Compton effect. Journal of Physics Conference Series (Vol. 909, No. 1).

Furh, Borko. 2011. Handbook of Augmented Reality. Florida. Springer

Jumriana, J. (2015). Development of Computer Based Tutorial Learning Model (MP-TBK) in ICT Subjects for Class X SMA Negeri 2 Palopo. Scientific Journal of Information Technology, 5 (2), 69-79.

Kortbek, K. J., \& Grønbæk, K. (2008). Interactive spatial multimedia for communication of art in the physical museum space. Paper presented at the Proceedings of the 16th ACM international conference on Multimedia. 
Kuswanto, J., \& Walusfa, Y. (2017). Development of Learning Multimedia in Class VIII Information and Communication Technology Subjects. Innovative Journal of Curriculum and Educational Technology, 6 (2), 1-7.

Lee, H., Billinghurst, M., \& Woo, W. (2011). Two-handed tangible interaction techniques for composing augmented blocks. Virtual Reality, 15(2-3), 133-146.

Mustaqim, I. (2017). Learning Media Development Based on Augmented Reality. Journal of Electrical Education, 1 (1).

Mustika, M., Rampengan, C. G., Sanjaya, R., \& Sofyan, S. (2015). Implementation of Augmented Reality as an Interactive Learning Media. Creative Information Technology Journal, 2 (4), 277-291.

Nasrullah, M., Malik, M. N., \& Muliadi, M. (2019). Pengembangan Teknologi Augmented Reality Sebagai Media Edukasi Masyarakat Terhadap Gizi Buruk. Jurnal Media TIK, 1(1).

Pratama, A. N., Habsary, D., \& Adzan, N. K. (2020). Web-Based E-Learning Media Enhanced Course in Dance Learning at SMK Ma'arif 5 Kotagajah. Journal of Arts and Learning, 8 (1).

Ramadhan, Ahmad Jery., Agustina, Ina., Gufroni, M. (2017). Three-dimensional (3D) Aircraft Takeoff Visualization Design. Journal of Information Technology and Computer Science (JOINTECS). 2 (2) 100-104.

Rifa'i, M., Listyorini, T., \& Latubessy, A. (2014). Penerapan Teknologi Augmented Reality pada aplikasi katalog rumah berbasis android. Prosiding SNATIF, 267-274.

Riyanda, A. R., \& Suana, W. (2019). Development of Basic Programming Learning Module Based on Adobe Flash CS6 for Class XI RPL Students. Journal of Information Technology and Vocational Education, 1 (2).

Riyanda, A. R. (2020). Learning Creativity, Parents 'Education Level, and Parents' Income Against Student Motivation at SMK Al-Huda Jatimulyo, South Lampung Regency. Journal of Educational Innovation and Information Technology (JIPTI), 1 (2), 56-61.

Riyanda, A. R., Herlina, K., \& Wicaksono, B. A. (2020). Evaluation of the Implementation of the Online Learning System at the Teaching and Education Faculty, University of Lampung. IKRA-ITH HUMANIORA: Journal of Social Affairs and Humanities, 4 (1), 66-71.

Ronald T. Azuma. (1997). A Survey of Augmented Reality. Jurnal Teleoperators and Virtual Environments 6. 355-385

Riyanda, A. R., Herlina, K., \& Wicaksono, B. A. (2020). Evaluation of the Implementation of the Online Learning System at the Teaching and Education Faculty, University of Lampung. IKRA-ITH HUMANIORA: Journal of Social Affairs and Humanities, 4 (1), 66-71..

Suana, W., Riyanda, A. R., \& Putri, N. M. A. A. (2019). Internet Access and Internet Self-efficacy of High School Students. Journal of Educational Science and Technology (EST), 5(2), 110117.

Suhiyar, A. B. (2017). Making Learning Media Introduction to Hardware For Interfaces in Data Communication and Interfaces Subjects. Journal of Electrical Engineering Education, 7 (2). 
Tomei, L.A. ed., (2007). Adapting Information and Communication Technologies for Effective Education (Vol. 2). IGI Global.

Vert, S., \& Vasiu, R. (2015). Integrating linked open data in mobile augmented reality applicationsa case study. Tem Journal, 4(1), 35.

Wiharto, A., \& Budihartanti, C. (2017). Augmented Reality Mobile Application as Learning Media for Introduction to Android-Based Computer Hardware. PROSISKO: Journal of Computer Systems Research 